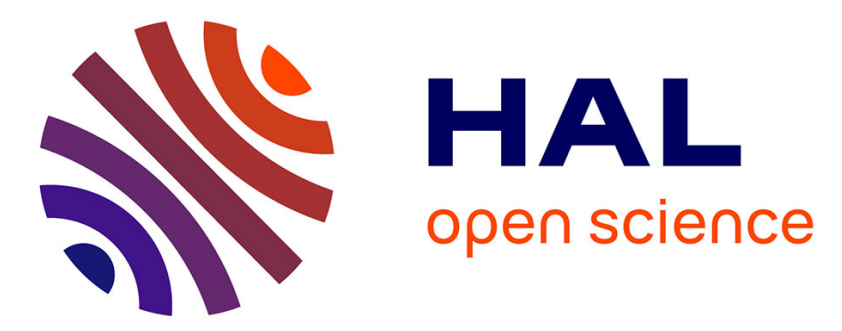

\title{
Niche overlap and species assemblage dynamics in an ageing pasture gradient in north-western France
}

Thibaut Decaens, Pierre Margerie, Jenny Renault, Fabrice Bureau, Magali Aubert, Mickael Hedde

\section{- To cite this version:}

Thibaut Decaens, Pierre Margerie, Jenny Renault, Fabrice Bureau, Magali Aubert, et al.. Niche overlap and species assemblage dynamics in an ageing pasture gradient in north-western France. Acta Oecologica, 2011, 37 (3), pp.212-219. 10.1016/j.actao.2011.02.004 . hal-02648502

\section{HAL Id: hal-02648502 \\ https://hal.inrae.fr/hal-02648502}

Submitted on 29 May 2020

HAL is a multi-disciplinary open access archive for the deposit and dissemination of scientific research documents, whether they are published or not. The documents may come from teaching and research institutions in France or abroad, or from public or private research centers.
L'archive ouverte pluridisciplinaire HAL, est destinée au dépôt et à la diffusion de documents scientifiques de niveau recherche, publiés ou non, émanant des établissements d'enseignement et de recherche français ou étrangers, des laboratoires publics ou privés. 
Original article

\title{
Niche overlap and species assemblage dynamics in an ageing pasture gradient in north-western France
}

\author{
T. Decaëns ${ }^{\mathrm{a}, *}$, P. Margerie ${ }^{\mathrm{a}}$, J. Renault ${ }^{\mathrm{a}}$, F. Bureau ${ }^{\mathrm{a}}$, M. Aubert $^{\mathrm{a}}$, M. Hedde $^{\mathrm{b}}$ \\ ${ }^{a}$ Laboratoire d'Ecologie, EA 1293 ECODIV, FED SCALE, UFR Sciences et Techniques, Université de Rouen, 76821 Mont Saint Aignan Cedex, France \\ ${ }^{\mathrm{b}}$ INRA-PESSAC, UR 251, Bâtiment 6, RD 10, 78026 Versailles Cedex, France
}

\section{A R T I C L E I N F O}

\section{Article history:}

Received 17 August 2009

Accepted 9 February 2011

Available online 10 March 2011

\section{Keywords:}

Grasslands

Assembly rules

Trait-based rules

Species-based rules

Null models

Niche overlap analysis

Gradient analysis

\begin{abstract}
A B S T R A C T
This study aims at describing the mechanisms of earthworm species assemblages in a temperate grassland ageing gradient. Earthworms were sampled by a combination of formaldehyde extraction and hand sorting. Density data were analysed by combining correspondence analysis (CA) and null model analyses of niche overlap patterns and morphological trait dispersion.

The first axis of the CA arranged samples according to the pasture ageing gradient and separated "pioneer" (CA1-) from "old pasture" (CA1+) species assemblages. The second axis segregated two different assemblages (CA2 - and $\mathrm{CA} 2+$ ) that were consistently represented along the ageing gradient and was assumed to represent intra-plot assemblage heterogeneity. Niche overlap according to soil organic C, C:N ratio and root biomass was higher than expected by chance (EBC) in most assemblages, and was higher when calculated for the whole regional species pool than for local assemblages. Morphological dispersion was random or lower than expected by chance for the regional species pool and both CA1 - and CA1+, and higher than expected by chance for both CA2 - and CA2+. These results indicate that: (1) habitat and dispersal constraints act as filters by allowing only those species with similar prerequisite traits into assemblages; (2) inter-specific competition limit composition in a further step by calling for a minimal level of overdispersion in morphological traits.
\end{abstract}

(C) 2011 Elsevier Masson SAS. All rights reserved.

\section{Introduction}

Identifying the main factors that drive the structure of ecological communities is an active research area in community ecology and is of particular importance for predicting biodiversity responses to global environmental changes (Belyea and Lancaster, 1999). Diamond (1975) first defined "assembly rules" as the general principles that predict which subset of a given regional species pool is sorted out by bio-physical factors to compose local assemblages. Assembly rules are assumed to generate non-random community patterns that may be detected through different approaches. Among others, null models consist in a randomisation of real data that produce community patterns expected in the absence of deterministic rules (Connor and Simberloff, 1979; Gotelli, 2001). They are useful to track and interpret non-random community patterns such as species co-occurrence levels, body-size or morpho-ecological structure, niche overlapping and species nestedness (Feeley, 2003; Gotelli and Ellison, 2002; Gotelli and McCabe, 2002; Ulrich and Gotelli, 2007).

\footnotetext{
* Corresponding author.

E-mail address: thibaud.decaens@univ-rouen.fr (T. Decaëns).
}

The power of null models for trait-based approaches has been widely advocated in recent years, and gives the method a particular interest to depict the relative importance of physical versus biotic factors in structuring natural communities (Franzén, 2004; Mouillot et al., 2007; Weiher and Keddy, 1995). For instance, in a competitively structured community, co-existing species should differ substantially in their resource uses (MacArthur and Levins, 1967; Schoener, 1974), so as morphological similarity and/or niche overlap among species should be lower than Expected By Chance (EBC) (Hutchinson, 1959; MacArthur and Levins, 1967; Weiher et al., 1998; Weiher and Keddy, 1995). On the other hand, abiotic environmental factors may also operate a control on communities by selecting among the regional species pool those species that present the best adapted traits for local environmental conditions. In this case, species co-existing in local assemblages should share environmentally-selected traits and thus present a higher trait similarity and/or a higher niche overlap than EBC (Keddy and Weiher, 1999; Keddy, 1992; Weiher et al., 1998; Weiher and Keddy, 1995).

To our knowledge, only a few studies investigated assembly rules in soil invertebrate communities. Within the few available examples appear the works of Gotelli and collaborators on ants 
(Albrecht and Gotelli, 2001; Gotelli and Ellison, 2002; Sanders et al., 2003), Brandl and Topp (1985) and Ribera et al. (2001) on ground beetles, Barker and Mayhill (1999) on terrestrial mollusks and Decaëns et al. (2009, 2008b) on earthworms. Given the importance of earthworms in sustaining major ecological processes and ecosystem goods and services in terrestrial ecosystems (Lavelle et al., 2006), the need for accurate models of their community dynamics represent a major challenge for soil ecology (Decaëns et al., 2006, 2008a).

In this study, we documented the successional patterns of earthworm species assemblages in recently set up temperate grasslands. We used multivariate and null model analyses to describe changes in species composition, morpho-ecological structure and niche overlap levels across a gradient of pasture ageing. This allowed us identifying the underlying mechanisms of co-existence and proposing tentatively some general assembly rules in temperate earthworm community.

\section{Material and methods}

\subsection{Study site}

The study was carried out at the "Lycée Agricole d'Yvetot" (Seine Maritime, France), on a loamy plateau located $200 \mathrm{~km}$ north-west from Paris. Climate is temperate oceanic with a mean annual temperature of $10{ }^{\circ} \mathrm{C}$ and a mean annual pluviometry of $800 \mathrm{~mm}$. The almost entire surface of the surrounding landscape is covered by a deep layer of loess material $(>80 \mathrm{~cm})$. Soils are LUVISOLs (French Classification; INRA, 1998), equivalent to Luvisols (FAO classification; ISSS-ISRIC-FAO, 1998); clay $=15 \%$, silt $=66 \%$ and sand $=19 \%$, mean $\mathrm{pH}\left(\mathrm{H}_{2} \mathrm{O}\right)=6.1$. Sampling sites were all located on the same topographic situation with no significant differences in soil properties between them.

Earthworms were sampled in April 2002 in 6 plots: an annual crop managed in rotations (maize, Zea mays L.; wheat, Triticum aestivum L.; beet, Beta vulgaris L.; flax, Linum usitatissimum L.), four grasslands managed in crop/pasture rotations and a permanent 32 year-old grassland. The crop/pasture set was assumed to represent a classical temporary grassland cycle, i.e., pastures that are established for a period of 4-8 years after two successive annual crops (maize and wheat). At the sampling date, the four temporary pastures were $0.5,1.5,6.5$ and 7.5 years-old respectively. The permanent pasture was chosen to represent the oldest local stage of pasture ageing gradient.

Before pasture establishment, soil was tilled (30 cm deep) and 50 tonnes ha ${ }^{-1}$ of cattle manure was superficially incorporated. At pasture establishment, mixed seeds of Lolium sp., Trifolium repens L., Festuca elatior L., Phleum pratense L. were sowed at a rate of $21 \mathrm{~kg} \mathrm{ha}^{-1}$. Thereafter, plant assemblages were not managed, $180 \mathrm{~kg}$ of $\mathrm{N} \mathrm{ha}^{-1}$ were applied annually, and the pastures were grazed for cattle milk production from mid-March to mid-September with a stocking rate of $2-5$ livestock units per ha according to the season.

The choice of carrying out this study in a true agricultural production unit was motivated by the wish of addressing large scale agricultural plots in order to produce data that reflect the realistic and complex impacts of agricultural practices on earthworm communities. One problem with that choice, however, was that the study site did not provided real plot replicates for each system. Despite this constraint, we consider that no significant pseudoreplication-induced bias was introduced in our results, this at least for two main reasons (Oksanen, 2001): (1) the intersampling distance used was higher than the scale of spatial autocorrelation in earthworm assemblages, i.e., $>20-30 \mathrm{~m}$ (Decaëns and Rossi, 2001; Margerie et al., 2001; Rossi and Lavelle, 1998); (2) we exclusively used multivariate and non-parametric statistics (permutation tests) and strictly avoided pair-wise comparisons of mean values among sampling plots.

\subsection{Earthworm and soil sampling}

Earthworm sampling was done during in April 2002. In each plot, 5 samples were taken on the corners and at the centre of a $20 \mathrm{~m}$-side square. The distance between sampling points was sufficient to avoid spatial autocorrelation and consider them as statistically independent from each others (Margerie et al., 2001). Sampling was done by a combination of formaldehyde extraction and hand sorting (Decaëns et al., 2003). Three successive aspersions of $10 \mathrm{~L}$ of $4 \%$ formaldehyde solution were applied on a $1 \mathrm{~m}^{2}$ area at regular time intervals of $15 \mathrm{~min}$. Expelled earthworms were fixed and stored in $4 \%$ formaldehyde solution. A soil block $(25 \times 25 \mathrm{~cm}-$ side, $30 \mathrm{~cm}$-depth) was then dug out in the centre of the square meter and hand sorted in the field and specimens were stored separately. This allowed estimating the density of individuals that were not successfully collected by formaldehyde extraction and to readjust density and biomass data when necessary. Earthworms were identified to species level according to Sims and Gerard (1985) as the main taxonomic reference, and Bouché (1972) when necessary. Species were further assigned to one of the three ecological categories of Bouché (1972): endogeics that live into the soil and feed on soil humus and dead roots, epigeics that live and feed at the soil on fresh organic matter and anecics that live in vertical burrows and forage organic detritus at the soil surface.

Four soil cores (6-cm-diameter, 10-cm-depth) were taken before earthworm sampling at each corner of the square metres. Soil was oven-dried at $40^{\circ} \mathrm{C}$ and sieved at $2 \mathrm{~mm}$. Organic $\mathrm{C}$ and total $\mathrm{N}$ were measured by CHN Analyser for an aliquot of each sieved sample, and $\mathrm{C}: \mathrm{N}$ ratio was computed from the obtained results. Roots were sampled by washing three of the four soil cores under a water spray on a $200 \mu \mathrm{m}$ mesh sieve, dried at $65^{\circ} \mathrm{C}$ for $48 \mathrm{~h}$ and weighed.

\subsection{Statistical and null model analyses}

\subsubsection{Correspondence analysis}

A correspondence analysis (CA) was done to reduce the dimensionality of density data set and to highlight the main patterns of earthworm assemblage composition along the pasture ageing gradient. The matrix used for this analysis contained 9 columns (species) and 30 rows (sampling points). This analysis and the corresponding figures were performed using the ade4 library for the $\mathrm{R}$ environment ( $\mathrm{R}$ Development Core Team, 2004; Thioulouse et al., 2004).

Species were grouped into assemblages according to their coordinates (positive or negative) on CA axes. This allowed identifying four assemblage types, i.e., species with positive and negative scores on axes 1 and 2 . These assemblages were further used to compute community structure indices, which were compared to the same indices calculated for the whole regional species pool (i.e., the total number of species found at the study site). This was done to explore the main driving factors of community assembly in the sampled grasslands.

\subsubsection{Niche overlaps analysis}

For each assemblage and the regional pool, we calculated niche overlap for three soil parameters assumed to constrain earthworm species distributions, i.e., organic $\mathrm{C}, \mathrm{C}: \mathrm{N}$ ratio and root biomass. Earthworms are in fact known to feed on plant litter, mammalian dung, soil organic matter and/or dead roots, depending on the ecological category they belong to (Bouché, 1972; Curry and Schmidt, 2007). In the case of grassland soils, litter production is expected to be low due to grazing pressure while dung production 
is likely random at the scale of our study. Soil total $\mathrm{C}$ and root biomass were thus assumed to represent two important niche parameters representative of food availability, with C:N giving an indication of the quality of the resource.

For each of these parameter, we computed the mean Pianka's index of niche overlap $\left(O_{\mathrm{jk}}\right)$. For species 1 and 2, with resource uses $p_{1 \mathrm{i}}$ and $p_{2 \mathrm{i}}$, Pianka's overlap index $\left(\mathrm{O}_{12}\right)$ is calculated using the following formula:

$O_{12}=O_{21}=\sum_{i=1}^{n} \frac{p_{2 i} p_{1 i}}{\sqrt{\sum_{i=1}^{n}\left(p_{2 i}\right)^{2}\left(p_{1 i}\right)^{2}}}$

To compute this index, soil variables were categorized into the following classes: $<10,10-20,20-30$ and $>30$ for $C$ concentration; $<9.5,9.5-10.5,10.5-11.0,11.0-11.5$ and $>11.5$ for $\mathrm{C}: \mathrm{N}$ ratio; $<100,100-200,200-300,300-400,400-500$ and $>500$ for root biomass $\mathrm{g} \mathrm{m}^{-2}$. Resource classes were weighted by their relative availability in records (Colwell and Futuyma, 1971). The calculation was thus performed for each soil parameter on a density matrix with 9 lines (species) and a number of column equivalent to the number of categories (i.e., 4 for $\mathrm{C}$ concentration, 5 for $\mathrm{C}: \mathrm{N}$ ratio, 6 for root biomass).

For each assemblage, observed mean niche overlap was compared with an EBC index calculated with a null model in which the data were randomized among species (10,000 iterations). If competitively structured, a given assemblage should present less niche overlap than EBC for the dimensions of the niche that are subject to competition. We used a randomization algorithm that retains the niche breadth of each species, but randomizes which particular resource states are utilized (RA3 in Albrecht and Gotelli, 2001). It corresponds to a simple reshuffling of each row of the matrix that assumes all the different resource states to be equally abundant (or usable) by all species. Analyses were done with the 'Niche Overlap' module of Ecosim (Gotelli and Entsminger, 2001).

\subsubsection{Morphometric analysis}

Morphological traits (Table 1) were taken from the available literature (Bouché, 1972; Sims and Gerard, 1985). Traits corresponding to numerical variables were categorized and a Multiple Correspondence Analysis (MCA) was computed on this coded matrix, which contained 9 rows (species) and 6 columns (morphological traits) (Tenenhaus and Young, 1985). The species scores on the axes of the MCA represented their respective position in the multivariate morphological space and were used to compute two kinds of indices (Weiher et al., 1998):

(1) the mean Nearest Neighbour Euclidean Distance (mNND), which is the average distance between each species and its nearest neighbor's species location in the multivariate morphological space. It provides an estimation of how species are clustered or underdispersed in the morphological trait space, i.e., how much they are morphologically similar in average (Weiher et al., 1998) (Fig. 1). If the index is less than 1, the pattern exhibits clustering or underdispersion, while a value greater than 1 indicates a trend toward overdispersion;

(2) the minimum spanning tree (MST) which is the size of the morphological volume of a given species assemblage. It is calculated as the minimum sum of $n-1$ segment lengths that connect the whole set of species within the morphological trait space in such a way that no loop is created (Ricklefs and Travis, 1980) (Fig. 1). It gives an idea of the ecological volume of resources occupied by the species assemblage.

For each assemblage, observed mNND and MST were compared with EBC indices calculated with a null model in which the data were randomized among species (10,000 iterations). If competitively structured, a given assemblage should present a higher mNND and MST than EBC. Conversely, lower mNND and MST than EBC would reflect the filtering effect of environmental factors that may select traits endowing species a better adaptation to local habitat conditions. We used a swapping algorithm based on the Manly shuffling procedure which keeps species richness and incidence constant while performing one swap per shuffle (Gotelli and Ellison, 2002; Manly, 1995). Both mNND and MST were also calculated separately for each sampling point to assess how environmental factors and species richness was related to assemblage morphological structure. Analyses were done with Nellie, Ecological Null Models for the PC (Swenson and Weiher, 2000).

\subsubsection{Non-parametric linear regressions}

We used non-parametric regressions to address the relationships between (1) grassland age and soil parameters and earthworm density, and (2) morphometric indices and soil parameters and species richness. Non-parametric regression fits a standard linear regression to the data set, and then uses randomization $(10,000$ iterations) to test the null hypothesis that the slope, intercept, or correlation coefficient equals 0 . Analyses were done using the 'Standard tests' module of Ecosim (Gotelli and Entsminger, 2001).

The standardized effect size (SES) was calculated for each index to allow cross-comparisons with other studies. SES measures the number of standard deviations for which the observed index is above or below the mean index obtained for the simulated communities (Gotelli, 2001). The null hypothesis is that the average SES measured for the entire data set is zero.

\section{Results}

\subsection{Pasture ageing gradient}

Organic $\mathrm{C}$ and $\mathrm{N}$ continuously increased along the pasture ageing gradient (Table 2). C: $\mathrm{N}$ ratio followed a similar but not significant pattern. Root biomass also tended to be significantly correlated with pasture age, although increase was not constant along the gradient and the corresponding $R^{2}$ was very low.

Table 1

List and main characteristics of the earthworm species collected in the study site (data from Bouché, 1972).

\begin{tabular}{|c|c|c|c|c|c|c|c|}
\hline Species name & Author & Ecological category & Body length (mm) & Diameter (mm) & Weight (g) & Epithelium type & Pigmentation \\
\hline Allolobophora chlorotica & Savigny, 1826 & Endogeic & $50-80$ & $3-7$ & $0.5-0.7$ & Supple & Absent \\
\hline Aporrectodea caliginosa & Savigny, 1826 & Endogeic & $60-80$ & $3.5-4.5$ & $0.2-0.85$ & Supple & Absent \\
\hline Aporrectodea icterica & Savigny, 1826 & Endogeic & $70-90$ & $3-4$ & $0.7-1.2$ & Supple & Absent \\
\hline Aporrectodea longa & Savigny, 1826 & Anecic & $130-170$ & $5.5-8$ & $1.2-3.8$ & Rigid & Present \\
\hline Aporrectodea rosea & Savigny, 1826 & Endogeic & $40-40$ & $2-3.5$ & $0.15-0.3$ & Supple & Absent \\
\hline Satchellius mammalis & Savigny, 1826 & Epigeic & $32-41$ & $1.5-2$ & $0.09-0.11$ & Supple & Present \\
\hline Lumbricus castaneus & Savigny, 1826 & Epigeic & $35-60$ & $2-2.5$ & $0.15-0.35$ & Supple & Present \\
\hline Lumbricus festivus & Savigny, 1826 & Epi-anecic & $65-95$ & $4-5$ & $0.75-1.2$ & Rigid & Present \\
\hline Lumbricus terrestris & Savigny, 1826 & Anecic & $130-250$ & $7-9$ & $5-15$ & Rigid & Present \\
\hline
\end{tabular}




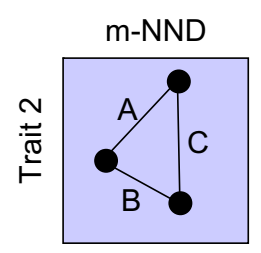

Trait 1

$$
=\frac{A+B+C}{3}=A+B
$$

Fig. 1. The different measurements of trait spacing, i.e., mean nearest neighbour in Euclidean distance (mNND) and minimum spanning tree in Euclidean distance (MST), in a two-dimensional niche illustrated by the position of three hypothetical species (from Franzén, 2004).

A total of nine species of Lumbricidae were identified, with representatives of the three ecological categories defined by Bouché (1972) (Tables 1 and 3). Species richness at the plot level (the number of species observed in a given plot) was lower in the crop and increased rapidly in the younger grasslands until a plateau was reached and remained constant along the ageing gradient (Table 2). The highest species richness and population density were observed for endogeic earthworms.

Earthworm density was weakly correlated with pasture age. In most cases, the important intra- and inter-plot variations resulted in low $R^{2}$ values $(<0.22)$ or a lack of significance of the permutation tests (in 7 tests out of 13). Among the few significant results, we found that total earthworm abundance was lower in the crop and consistently increased with pasture ageing (Table 2). This pattern was also observed for epigeic and endogeic species, while anecics seemed to respond non-linearly to the ageing gradient. Individual species populations were significantly enhanced by grassland ageing in only 3 cases out of 9 (i.e., Satchellius mammalis, Aporrectodea caliginosa and Aporrectodea icterica).

\subsection{Correspondence analysis}

The two first axes accounted for $53.1 \%$ of the total variance, with $31.7 \%$ and $21.4 \%$ for CA1 and CA2, respectively (Fig. 2a). The first axis opposed the crop and the 0.5 -yr old pasture from older pastures (negative and positive scores, respectively; Fig. 2b). Lumbricus terrestris, Aporrectodea rosea and Lumbricus festivus displayed negative scores on this axis and were opposed to A. icterica (Fig. 2c). This axis was assumed to reflect the successional changes occurring in earthworm communities during pasture ageing. Species with negative or positive scores were thus considered as characteristic of "early" and "mature stages" of grassland ageing, respectively, and were referred as $\mathrm{CA}^{-}$and $\mathrm{CA} 1^{+}$assemblages thereafter (Fig. $2 \mathrm{~d}$ ).

The ordination of sampling points on the second axis did not discriminated plots according to a clear pattern (Fig. 2b). Instead, most plots presented a high dispersion of their corresponding samples on this axis. However, species ordination opposed two distinct species assemblages. Lumbricus castaneus, Aporrectodea longa, A. rosea and A. icterica (referred as $\mathrm{CA}^{+}{ }^{+}$assemblage thereafter) had positive scores on axis 2 , and was opposed to $S$. mammalis, L. festivus, L. terrestris, A. caliginosa and Allolobophora chlorotica (referred as $\mathrm{CA}^{-}$assemblage) (Fig. 2e). This axis was assumed to represent the intra-plot heterogeneity in community composition, i.e., the spatial opposition of $\mathrm{CA}_{2}^{+}$and $\mathrm{CA}^{-}$ assemblages.

\subsection{Null model analyses}

Pinkas's overlap index was significantly higher than EBC whatever the niche axis and the species assemblage considered (Table 4). On the other hand, the mean SES was higher for the regional species pool than for the assemblages identified on the CA axes in all cases except one.

Both mNND and MST presented very similar patterns. They were equal than EBC when calculated for the regional species pool, as a consequence of the algorithm used for the null simulations. They were lower than EBC when calculated on $\mathrm{CA} 1$ - and $\mathrm{CA} 1+$, although this trend was significant only in the case of mNND calculated for $\mathrm{CA} 1+$. Conversely, both indices were significantly higher than EBC when calculated for CA2- and CA2+ (Table 5).

A positive and significant correlation was found between soil organic carbon concentration and both MST and mNND (Fig. 3a and b). No relationship was observed between species richness and mNND, whereas species richness was correlated positively and significantly with MST (Fig. 3 and d).

\section{Discussion}

\subsection{Earthworm density and species richness}

Population density and species richness found in our study are broadly in the range of previously published results for temperate agroecosystems (Decaëns et al., 1997, 2003, 2008b; Pižl, 1992; Scheu, 1992; Topoliantz et al., 2000). The low presence of earthworms in the annual crop is consistent with the well recognized negative impacts of cultivated systems on earthworm activity (Haynes et al., 2003). The general increase of populations during grassland ageing is probably due to an increased availability of trophic resources such as soil organic matter, surface litter and dead roots.

An interesting point is that the local species richness (i.e., the number of species found in a given plot) never comprised more than 9 species. This is a feature that appears to be almost constant in every part of the world, as earthworm local assemblages rarely overpass 8-10 species whatever the size of the regional pool (Decaëns et al., 2008b; Fragoso et al., 1999; Lavelle and Spain, 2001; Lee, 1985; Wardle, 2002). This limitation suggests a non-linear relationship between local and regional richness, which may reflect that local processes (i.e., competition) reduce the number of coexisting species due to rapid niche saturation (Decaëns et al., 2008b; Hillebrand, 2005). High levels of inter-specific competition are in fact expected to occur within earthworm communities, due to the high species adaptability and ecological plasticity between juveniles and adults. These traits may lead to a rapid saturation of the

Table 2

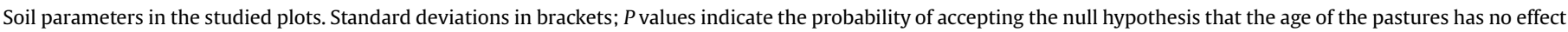

\begin{tabular}{|c|c|c|c|c|c|c|c|c|c|c|c|c|c|c|}
\hline \multirow[b]{2}{*}{ Organic $\mathrm{C}\left(\mathrm{g} \mathrm{kg}^{-1}\right)$} & \multicolumn{2}{|c|}{ Crop } & \multicolumn{2}{|c|}{ 0.5-year pasture } & \multicolumn{2}{|c|}{ 1.5-year pasture } & \multicolumn{2}{|c|}{ 6.5-year pasture } & \multicolumn{2}{|c|}{ 7.5-year pasture } & \multicolumn{2}{|c|}{ Permanent pasture } & \multirow{2}{*}{$\begin{array}{l}R^{2} \\
0.72\end{array}$} & \multirow{2}{*}{$\begin{array}{l}P \text { value } \\
0.000\end{array}$} \\
\hline & 9.3 & $(0.1)$ & 14.5 & $(0.3)$ & 16.6 & $(0.6)$ & 24.3 & $(0.4)$ & 28.9 & $(0.1)$ & 37.3 & $(0.1)$ & & \\
\hline Total $\mathrm{N}\left(\mathrm{g} \mathrm{kg}^{-1}\right)$ & 1.0 & $(0.0)$ & 1.5 & $(0.0)$ & 1.6 & $(0.1)$ & 2.1 & $(0.0)$ & 2.6 & $(0.1)$ & 3.5 & $(0.0)$ & 0.67 & 0.000 \\
\hline C-to-N ratio & 9.1 & $(0.1)$ & 9.9 & $(0.1)$ & 10.5 & $(0.2)$ & 11.5 & $(0.0)$ & 11.1 & $(0.1)$ & 10.8 & $(0.1)$ & 0.09 & 0.052 \\
\hline Root biomass $\left(\mathrm{g} \mathrm{m}^{-2}, \mathrm{dw}\right)$ & 0.0 & $(0.0)$ & 149.5 & (1.9) & 372.3 & $(27.2)$ & 646.1 & $(34.6)$ & 384.9 & $(18.6)$ & 560.4 & $(50.4)$ & 0.24 & 0.005 \\
\hline
\end{tabular}
soil properties. 
Table 3

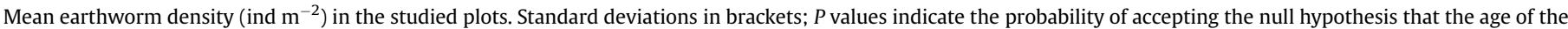
pastures has no effect on earthworm density.

\begin{tabular}{|c|c|c|c|c|c|c|c|c|c|c|c|c|c|c|}
\hline \multicolumn{3}{|c|}{ Crop } & \multicolumn{2}{|c|}{ 0.5-year pasture } & \multicolumn{2}{|c|}{ 1.5-year pasture } & \multicolumn{2}{|c|}{ 6.5-year pasture } & \multicolumn{2}{|c|}{ 7.5-year pasture } & \multicolumn{2}{|c|}{ Permanent pasture } & \multirow{2}{*}{$\frac{R^{2}}{0.22}$} & \multirow{2}{*}{$\begin{array}{l}P \text { value } \\
0.019\end{array}$} \\
\hline S. mammalis & 0.00 & $(0.00)$ & 4.20 & $(3.10)$ & 5.60 & $(3.83)$ & 14.60 & $(4.91)$ & 24.00 & $(9.01)$ & 34.80 & $(19.68)$ & & \\
\hline L. castaneus & 0.00 & $(0.00)$ & 2.20 & $(0.58)$ & 4.02 & $(1.26)$ & 21.44 & $(8.06)$ & 2.20 & $(1.02)$ & 5.76 & (3.38) & 0.00 & 0.347 \\
\hline Total epigeics & 0.00 & $(0.00)$ & 6.40 & $(3.41)$ & 9.62 & $(4.74)$ & 36.04 & $(9.80)$ & 26.20 & $(8.76)$ & 40.56 & (19.18) & 0.20 & 0.022 \\
\hline L. terrestris & 5.33 & $(5.33)$ & 0.00 & (1.31) & 36.92 & (11.67) & 3.36 & (1.29) & 0.34 & $(0.21)$ & 2.38 & $(1.49)$ & -0.05 & 0.088 \\
\hline L. festivus & 0.00 & $(0.00)$ & 0.60 & $(1.26)$ & 15.04 & $(4.32)$ & 2.80 & $(0.86)$ & 1.66 & $(0.84)$ & 1.88 & $(1.06)$ & -0.03 & 0.187 \\
\hline A. longa & 0.00 & $(0.00)$ & 15.60 & $(25.04)$ & 92.20 & $(8.82)$ & 106.40 & $(15.00)$ & 47.40 & $(10.36)$ & 34.80 & $(10.84)$ & -0.01 & 0.306 \\
\hline Total anecics & 5.33 & (5.33) & 16.20 & $(5.53)$ & 144.16 & (14.41) & 112.56 & (14.62) & 49.40 & (10.47) & 39.06 & (11.35) & -0.03 & 0.201 \\
\hline A. chlorotica & 0.00 & $(0.00)$ & 1.20 & (18.97) & 8.80 & $(4.13)$ & 16.80 & $(7.63)$ & 7.00 & $(3.90)$ & 23.80 & $(22.32)$ & 0.10 & 0.122 \\
\hline A. rosea & 5.33 & (5.33) & 14.12 & (19.32) & 21.86 & (10.13) & 13.98 & $(6.36)$ & 19.80 & (19.05) & 3.60 & (3.36) & -0.04 & 0.162 \\
\hline A. caliginosa & 16.00 & (9.24) & 14.80 & $(24.40)$ & 145.20 & (37.17) & 98.40 & $(22.37)$ & 161.80 & (33.57) & 175.20 & $(57.92)$ & 0.17 & 0.022 \\
\hline A. icterica & 0.00 & $(0.00)$ & 9.76 & (13.58) & 13.94 & $(5.44)$ & 77.02 & (20.94) & 99.60 & (35.91) & 90.20 & (3.97) & 0.22 & 0.011 \\
\hline Total endogeics & 21.33 & (10.67) & 39.88 & $(64.53)$ & 189.80 & (41.17) & 206.20 & $(34.32)$ & 288.20 & (57.30) & 292.80 & $(78.84)$ & 0.22 & 0.009 \\
\hline TOTAL & 26.67 & (14.11) & 62.48 & (104.69) & 343.58 & (51.96) & 354.80 & (51.57) & 363.80 & $(64.31)$ & 372.42 & $(93.80)$ & 0.14 & 0.027 \\
\hline
\end{tabular}

ecological space and a relative uniformity in species richness among communities (Lavelle and Spain, 2001; Wardle, 2002).

\subsection{Earthworm species composition and assemblages}

The results of the correspondence analyses clearly point for grassland ageing as the main factor for explaining earthworm assemblage composition. Four species ( $A$. rosea, A. longa, L. terrestris and $L$. festivus) seemed to represent a "pioneer assemblage" of the crop and/or the youngest pasture, or a set of species that were more efficient than others in reconstituting their population after crop disturbance (CA1 - assemblage). In the annual crop, A. caliginosa was also present with significant densities. This result agrees with the study of Topoliantz et al. (2000) and Decaëns et al. (2008b) who identified $A$. rosea, $A$. caliginosa, $L$. terrestris and to a lower extent A. longa as dominant species in temperate arable systems. All these species are known for their large high ecological plasticity and adaptability to agricultural systems (Bouché, 1972; Sims and Gerard, 1985). Additionally, the small size of $A$. rosea and $A$. caliginosa may enhance their survival ability in deeply ploughed systems, while the high vagility of the larger anecic species may provide them with a high colonisation capacity in recently settled pastures (Topoliantz et al., 2000; Wyss and Glasstetter, 1992). Conversely, the older
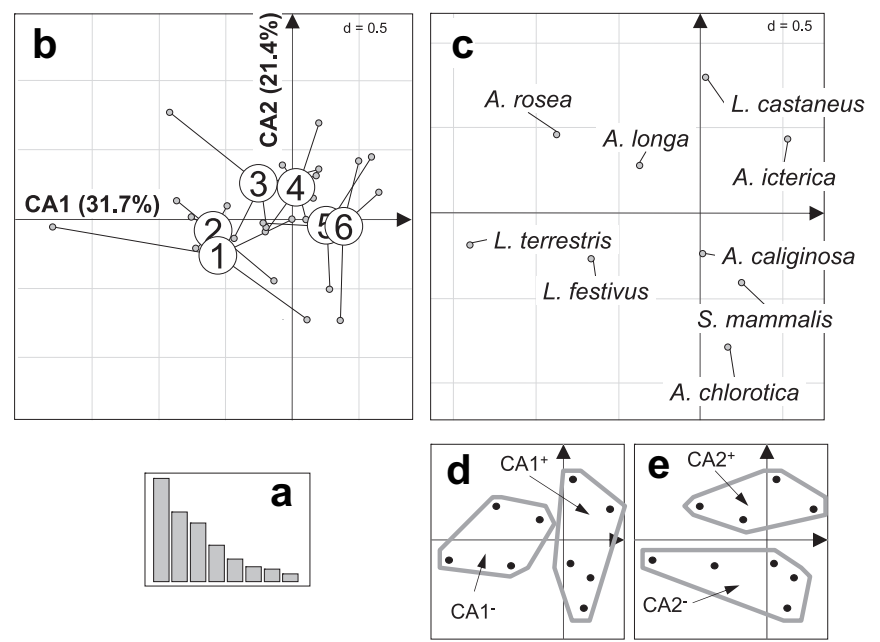

Fig. 2. Results of the CA of earthworm species in crop and pasture with different ages (first factorial plan: CA1-CA2): (a) eigenvalues diagram; (b) site ordination with representation of the gravity centres of each plot; (c) species ordination; (d) species assemblages identified on the first two axes (see text for details). $1=$ Annual crop; $2=0.5$-yr pasture; $3=1.5$-yr pasture; $4=6.5$-yr pasture; $5=7.5$-yr pasture; $6=$ Permanent pasture. pastures were dominated by $L$. castaneus, A. icterica, A. caliginosa, $S$. mammalis and $A$. chlorotica (PA1+ assemblages). This group of species, which may be referred as "old pasture species", was composed by epigeic and endogeic species known to build up large populations in temperate pastures (Decaëns et al., 2008b).

The second axis of the CA clearly segregated two different species assemblages that were both represented along the whole ageing gradient (PA2- and $\mathrm{PA} 2+$ assemblages). This suggests a strong spatial structuring of species assemblages at the plot scale. Spatial patterns in earthworm species assemblages at this scale have been described in a range of grassland types. In most cases, species are aggregated in patches over ranges of 20-50 m, each of them characterized by a dominant species assemblage (Decaëns and Rossi, 2001; Jimenez et al., 2001; Margerie et al., 2001; Nuutinen et al., 1998; Rossi, 2003; Rossi and Lavelle, 1998). The two species assemblages identified on CA2 may in fact result from such a spatial patterning, and correspond to the dominant assemblages of two different types of patches that are repeatedly found across the pasture gradient. The identification of the determinants structuring earthworm species assemblages is addressed bellow through the null model approach.

\subsection{Niche overlap patterns}

We found that earthworm species assemblages were characterised by a high niche overlap with regard to organic $\mathrm{C}, \mathrm{C}: \mathrm{N}$ ratio

Table 4

Results of the niche overlap analysis. For each niche dimension, we calculated the observed (Obs) and simulated (EBC for expected by chance) Pianka's index for both the regional scale - assemblage (the list of species identified for the whole study site) and for the four assemblages identified from the correspondence analysis (CA1 -, CA1 +, CA2 - and CA2 + for species with negative or positive scores on CA1 and $C A 2$, respectively). The $P$ values indicate the probability of accepting the null hypothesis that the standardized effect size (SES) differed from zero.

\begin{tabular}{llllll}
\hline Niche dimension & Assemblages & Obs Pianka & EBC Pianka & Average SES & $P$ \\
\hline Root biomass & Regional & 0.81 & 0.65 & 6.58 & 0.000 \\
Root biomass & CA1- & 0.84 & 0.63 & 3.10 & 0.005 \\
Root biomass & CA1+ & 0.84 & 0.66 & 3.75 & 0.002 \\
Root biomass & CA2- & 0.85 & 0.63 & 4.25 & 0.001 \\
Root biomass & CA2+ & 0.83 & 0.67 & 2.70 & 0.012 \\
C-to-N ratio & Regional & 0.76 & 0.63 & 4.31 & 0.003 \\
C-to-N ratio & CA1- & 0.80 & 0.65 & 2.29 & 0.033 \\
C-to-N ratio & CA1+ & 0.87 & 0.61 & 4.38 & 0.001 \\
C-to-N ratio & CA2- & 0.63 & 0.55 & 1.08 & 0.142 \\
C-to-N ratio & CA2+ & 0.90 & 0.72 & 3.26 & 0.005 \\
Organic C & Regional & 0.85 & 0.56 & 6.79 & 0.000 \\
Organic C & CA1- & 0.93 & 0.56 & 3.56 & 0.003 \\
Organic C & CA1+ & 0.95 & 0.57 & 4.90 & 0.000 \\
Organic C & CA2- & 0.80 & 0.62 & 2.61 & 0.018 \\
Organic C & CA2 + & 0.94 & 0.53 & 3.75 & 0.001 \\
\hline
\end{tabular}


Table 5

Trait dispersion indices analyses. For each metric (mNND and MST), we calculated the observed (Obs) and simulated (EBC for expected by chance) values for both the regional scale - assemblage (the list of species identified for the whole study site) and for the four assemblages identified from the correspondence analysis (CA1-, $\mathrm{CA} 1+, \mathrm{CA} 2$ - and CA2 + for species with negative or positive scores on CA1 and CA2, respectively). The $P$ values indicate the probability of accepting the null hypothesis that the standardized effect size (SES) differed from zero; significant values at the probability level of $p=0.05$ are indicated in italics.

\begin{tabular}{llllcl}
\hline Metric & Scale & Obs value & EBC value & Average SES & $P$ \\
\hline mNND & Regional & 0.63 & 0.63 & 0.00 & 1.000 \\
mNND & CA1- & 1.11 & 1.23 & -0.39 & 0.496 \\
mNND & CA1+ & 0.70 & 1.01 & -0.95 & 0.022 \\
mNND & CA2- & 1.65 & 1.28 & 1.17 & 0.000 \\
mNND & CA2+ & 1.50 & 0.64 & 2.66 & 0.025 \\
MST & Regional & 8.65 & 8.65 & 0.00 & 1.000 \\
MST & CA1- & 4.42 & 4.60 & -0.57 & 0.496 \\
MST & CA1+ & 4.56 & 5.77 & -3.79 & 0.083 \\
MST & CA2- & 7.18 & 5.72 & 4.56 & 0.000 \\
MST & CA2+ & 5.10 & 3.53 & 4.89 & 0.050 \\
\hline
\end{tabular}

and root biomass. This means that whatever the combination of species found in a given assemblage, resource utilisation among species was more similar than EBC. This suggests a strong importance of environmental constraints on membership in assemblages (Keddy and Weiher, 1999; Keddy, 1992; Weiher et al., 1998; Weiher and Keddy, 1995). Ecological theory predicts that environmental conditions acting as strong habitat filters may induce an underdispersion of the traits associated with these pressures. Trophic resource availability and quality are known to represent, together with soil compaction, the main ecological constraints for soil animals (Lavelle and Spain, 2001). As a consequence, earthworms may tend to concentrate in areas where soil organic matter is more abundant, C:N ratio is lower, and/or root biomass is higher (Decaëns et al., 2009). This ma y account for species distribution at different scales, i.e., from their distribution along the pasture ageing gradient to their structuring in segregated species assemblages at the plot scale.

On the other hand, we found that average SES was in most cases lower in CA-defined patches than when calculated for the whole regional species pool. This suggests that competition is reduced in dominant assemblages by limiting ecological similarity between species that co-exist at these scales. A similar result was observed by Decaëns et al. (2009) in spatially structured earthworm assemblages of tropical grasslands. In our study, it is worth noticing that this pattern was observed for the characteristic assemblages of the ageing gradient extremes (i.e., pioneer species versus mature pasture species) as well as for the two assemblages opposed at the plot scale.

\subsection{Trait dispersion patterns}

The null model analysis of trait dispersion provided contrasted results depending on the species assemblages considered. We found that morphological traits among species were random or more similar than EBC (negative average SES) in assemblages segregated on the pasture ageing gradient (CA1 - and CA1+). Again, this probably reflects the impact of environmental constraints in selecting species with particular adaptations or ecological requirements (Keddy and Weiher, 1999; Keddy, 1992; Weiher et al., 1998; Weiher and Keddy, 1995). For instance, large pigmented anecics (L. terrestris, L. festivus and A. longa) with high dispersal abilities tended to be dominant in the younger stages of the gradient ageing, while smaller and non-pigmented endogeics increased in density in the older pastures, probably as a result of the higher levels of organic matter levels.

Conversely, we observed that the same traits were overdispersed (i.e., less similar than EBC) in both CA2 - and CA2+ assemblages This suggests that species should differ in morphology in order to reduce resource use overlap and co-exist in a given patch (Dayan and Simberloff, 2005; Weiher and Keddy, 1995; MacArthur

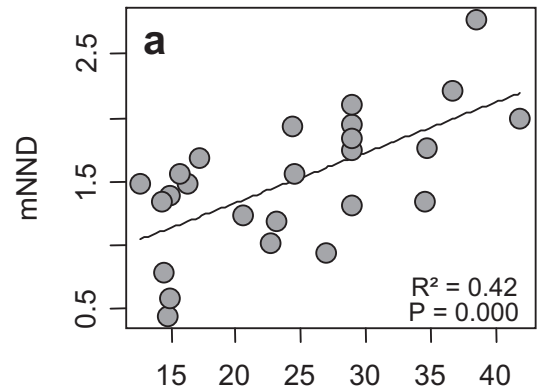

Organic carbon content $\left(\mathrm{g} \mathrm{kg}^{-1}\right)$

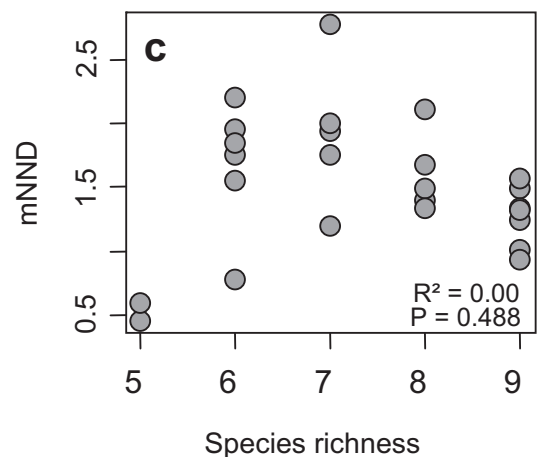

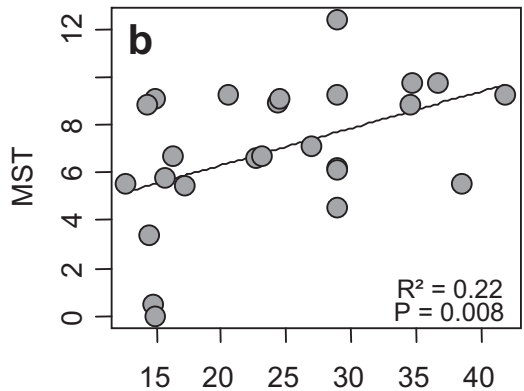

Organic carbon content $\left(\mathrm{g} \mathrm{kg}^{-1}\right)$

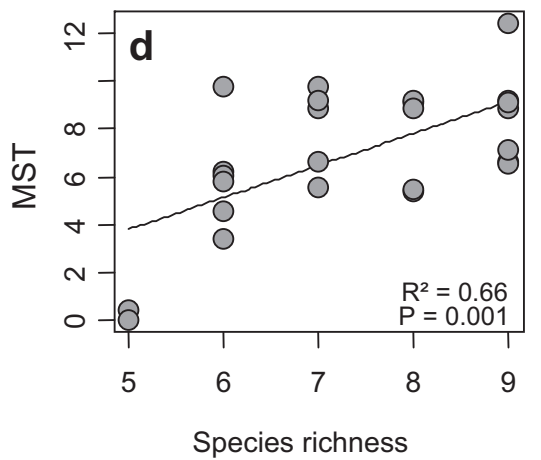

Fig. 3. Relationships between observed (i) mNND and MST and (ii) soil organic carbon concentration (a, b) and species richness (c, d). 
and Levins, 1967). Such patterns of limiting similarity have been previously reported for several groups of soil invertebrates such as molluscs (Barker and Mayhill, 1999; Grudemo and Johannesson, 1999), crustaceans (Marchinko et al., 2004), beetles (Brandl and Topp, 1985; Satoh et al., 2003; Sota et al., 2000), and ants (Gotelli and Ellison, 2002; Nipperess and Beattie, 2004). The few earthworm studies that addressed this question also suggested that morphological features are directly related to resource utilization and that a minimal level of inter-specific trait differentiation is necessary in stable assemblages (Decaëns et al., 2009; Fragoso and Rojas, 1997; Jiménez and Rossi, 2006). Body weight is, for example, known to reflect the quality of the resource ingested by endogeic species (Lavelle, 1981): small species are often specialized for organic-rich substrates (e.g., litter, root exudates, vertebrate faeces, etc.), while larger ones usually ingest soil with lower organic concentration. Species body length is reported to correlate with the size of the ingested particles (Blanchart et al., 1997; Lowe and Butt, 2003). Pigmentation is also known to be linked with feeding behaviour: pigmented species (anecics and epigeics) typically feed on litter, while non-pigmented (endogeics) usually feed on organomineral substrate (Bouché, 1972; Lavelle, 1981). Our results broadly support these statements by demonstrating that despite they tend to aggregate in organic-rich areas, earthworm species should differ substantially in the specific way they use trophic resources to coexist locally.

The positive correlation observed between morphological dispersion (both mNND and MST) in earthworm assemblages and organic $C$ levels suggests that competition increases with resource availability. This supports the idea that the relationship between trait dispersion and competition intensity/resource availability may be considered as a general property of both plant and animal communities (Twolan-Strutt and Keddy, 1996; Weiher et al., 1998). Another interesting result of our study is the positive correlation between MST and species richness, while mNND remained unchanged. A similar pattern was reported by Ricklefs and Miles (1994) in a review of animal assemblages. It suggests that the edges of assemblages are not fixed in morphological space. As species are added to assemblages, they tend to be accommodated at the periphery of existing morphological volume, whereas internal spacing appears to be conserved. In other words, the ecological space used by assemblages seems to saturate rapidly as species richness increases, and new colonising species are allowed to establish successfully only if they can use marginal resources not yet mobilised by the pre-established assemblage.

\section{Conclusions}

Earthworm assemblages in the studied grassland ageing gradient are simultaneously underdispersed and overdispersed. While underdispersion mostly corresponds to a low differentiation of niche breadth on gradients of trophic resources, overdispersion was observed at a morphological level. As stated by Weiher et al. (1998), this indicates that two kinds of assembly rules are operating simultaneously. Some assembly rules work as filters, allowing only those species with similar prerequisite traits into assemblages, while others work as a sorting device, calling for an overdispersion of trait mixture within assemblages. This supports the idea that habitat and dispersal constraints first limit assemblage composition according to species ability to colonise and inhabit a site, i.e., through capacity rules, while interactions limit composition in a further step through allocation rules (Belyea and Lancaster, 1999; Brown, 1987).

\section{Acknowledgements}

This work was supported by grant from the Conseil Régional de Haute-Normandie through the GRR SER and by a funding from the GESSOL program (DMOSTRA project, (Balabane et al., 2005)). We are grateful to the D. Guéroux (Lycée Agricole d'Yvetot) for providing field sampling facilities.

\section{References}

Albrecht, M., Gotelli, N.J., 2001. Spatial and temporal niche partitioning in grassland ants. Oecologia 126, 134-141.

Balabane, M., Bureau, F., Decaëns, T., Akpa, M., Hedde, M., Laval, K., Puget, P., Pawlak, B., Barray, S., Cluzeau, D., Labreuche, J., Bodet, J.M., Le Bissonnais, Y., Saulas, P., Picard, D., Guichard, L., Bertrand, M., Houot, S., Arrouays, D. Brygoo, Y.D.T.C.C., 2005. Restauration de fonctions et propriétés des sols de grande culture intensive: effets de systèmes de culture alternatifs sur les matières organiques et la structure des sols limoneux, et approche du rôle fonctionnel de la diversité biologique des sols. Ministère de l'Ecologie et du Développement Durable, Paris.

Barker, G.M., Mayhill, P.C., 1999. Patterns of diversity and habitat relationships in terrestrial mollusc communities of the Pukeamaru ecological district, northeastern New Zealand. Journal of Biogeography 26, 215-238.

Belyea, L.R., Lancaster, J., 1999. Assembly rules within a contingent ecology. Oikos $86,402-416$.

Blanchart, E., Lavelle, P., Braudeau, E., le Bissonnais, Y., Valentin, C., 1997. Regulation of soil structure by geophagous earthworm activities in humid savannas of Côte d'Ivoire. Soil Biology and Biochemistry 29, 431-439.

Bouché, M., 1972. Lombriciens de France. Ecologie et Systématique. Institut National de Recherches Agronomiques, Paris.

Brandl, R., Topp, W., 1985. Size structure of Pterostichus spp. (Carabidae): aspects of competition. Oikos 44, 234-238.

Brown, J.H., 1987. Variation in desert rodent guilds: patterns, processes, scales. In: Gee, J.H.R., Giller, P.S. (Eds.), Organization of Communities: past and present. Blackwell, Oxford, pp. 185-203.

Colwell, R.K., Futuyma, D.J., 1971. On the measurement of niche breadth and overlap. Ecology 52, 567-576.

Connor, E.F., Simberloff, D., 1979. The assembly of species communities: chance or competition? Ecology 60, 1132-1140.

Curry, J.P., Schmidt, O., 2007. The feeding ecology of earthworms - a review. Pedobiologia 50, 463-477.

Dayan, T., Simberloff, D., 2005. Ecological and community-wide character displacement: the next generation. Ecology Letters 8, 875-894.

Decaëns, T., Bureau, F., Margerie, P., 2003. Earthworm communities in a wet agricultural landscape of the seine valley (Upper Normandy, France). Pedobiologia 47, 479-489.

Decaëns, T., Dutoit, T., Alard, D., 1997. Earthworm community characteristics during afforestation of abandoned chalk grasslands (Upper Normandy, France). European Journal of Soil Biology 33, 1-11.

Decaëns, T., Jiménez, J.J., Gioia, C., Measey, G.J., Lavelle, P., 2006. The values of soil animals for conservation biology. European Journal of Soil Biology 42, S23-S38.

Decaëns, T., Jiménez, J.J., Rossi, J.-P., 2009. A null-model analysis of the spatiotemporal distribution of earthworm species assemblages in Colombian grasslands. Journal of Tropical Ecology 25, 415-427.

Decaëns, T., Lavelle, P., Jiménez, J.J., 2008a. Priorities for conservation of soil animals. CAB reviews: perspectives in agriculture, veterinary science. Nutrition and Natural Resources 3.

Decaëns, T., Margerie, P., Aubert, M., Hedde, M., Bureau, F., 2008b. Assembly rules within earthworm communities in north-western France - a regional analysis. Applied Soil Ecology 39, 321-335.

Decaëns, T., Rossi, J.-P., 2001. Spatio-temporal structure of earthworm community and soil heterogeneity in a tropical pasture. Ecography 24, 671-682.

Diamond, J.M., 1975. Assembly of species community. In: Cody, M.L., Diamond, J.M. (Eds.), Ecology and Evolution of Communities. Harvard Univ. Press, Cambridge, pp. 342-444.

Feeley, K., 2003. Analysis of avian communities in Lake Guri, Venezuela, using multiple assembly rule models. Oecologia 137, 104-113.

Fragoso, C., Rojas, P., 1997. Size shift in the Mexican earthworm species Balanteodrilus pearsei (Megascolecidae, Acanthodrilini): a possible case of character displacement. Soil Biology and Biochemistry 29, 237-240.

Fragoso, C., Lavelle, P., Blanchart, E., Senapati, B.K., Jiménez, J.J., Martínez, M.A Decaëns, T., Tondoh, J., 1999. Earthworm communities of tropical agroecosystems. Origin, structure and influence of management practices. In: Lavelle, P., Brussaard, L., Hendrix, P.F. (Eds.), Earthworm Management in Tropical Agroecosystems. CAB-I, Wallingford, UK, pp. 27-55 (Chapter 2).

Franzén, D., 2004. Plant species coexistence and dispersion of seed traits in a grassland. Ecography 27, 218-224.

Gotelli, N.J., 2001. Research frontiers in null model analysis. Global Ecology and Biogeography 10, 337-343.

Gotelli, N.J., Ellison, A.M., 2002. Assembly rules for new England ant assemblages. Oikos 99, 591-599. 
Gotelli, N.J., Entsminger, G.L., 2001. Ecosim: Null Models Software for Ecology, Version 6.10. Acquired Intelligence Inc. \& Kesey-Bear.

Gotelli, N.J., McCabe, D.J., 2002. Species co-occurrence: a meta-analysis of J.M. Diamond's assembly rules model. Ecology 83, 2091-2096.

Grudemo, J., Johannesson, K., 1999. Size of mudsnails, Hydrobia ulvae (Pennant) and $\mathrm{H}$-ventrosa (Montagu), in allopatry and sympatry: conclusions from field distributions and laboratory growth experiments. Journal of Experimental Marine Biology and Ecology 239, 167-181.

Haynes, R.J., Dominy, C.S., Graham, M.H., 2003. Effect of agricultural land use on soil organic matter status and the composition of earthworm communities in KwaZulu-Natal, South Africa. Agriculture, Ecosystems and Environment 95, 453-464.

Hillebrand, H., 2005. Regressions of local on regional diversity do not reflect the importance of local interactions or saturation of local diversity. Oikos 110 , 195-198.

Hutchinson, G.E., 1959. Homage to Santa Rosalia and why are there so many kinds of animals? The American Naturalist 93, 145-159.

INRA, 1998. A Sound Reference Base for Soils - "Référentiel Pédologique". INRA, Paris.

ISSS-ISRIC-FAO, 1998. World Reference Base for Soil Resources. World Soil Resources Reports, Rome, 98 pp.

Jimenez, J.J., Rossi, J.-P., Lavelle, P., 2001. Spatial distribution of earthworms in acidsoil savannas of the eastern plains of Colombia. Applied Soil Ecology 17, 267-278.

Jiménez, J.J., Rossi, J.P., 2006. Spatial dissociation between two endogeic earthworms in the Colombian "Llanos". European Journal of Soil Biology 42, S218-S224.

Keddy, P.A.M., 1992. Assembly and response rules: two goals for predictive community ecology. Journal of Vegetation Science 3, 157-164.

Keddy, P, Weiher, E, 1999. The scope and goals of research on assembly rules. In: Weiher, E., Keddy, P. (Eds.), Ecological Assembly Rules. Perspectives, Advances, Retreats. Cambridge University Press, Cambridge, pp. 1-20.

Lavelle, P., 1981. Statégies de reproduction chez les vers de terre. Acta Ecologica Ecologia Generalis 2, 117-133.

Lavelle, P., Decaëns, T., Aubert, M., Barot, S., Blouin, M., Bureau, F., Margerie, P., Mora, P., Rossi, J.P., 2006. Soil invertebrates and ecosystem services. European Journal of Soil Biology 42, S3-S15.

Lavelle, P., Spain, A.V., 2001. Soil Ecology. Kluwer Academic Publishers, Dordrecht.

Lee, K.E., 1985. Eartwhworms. Their Ecology and Relationships with Soils and Land Use. Academic Press, Orlando.

Lowe, C.N., Butt, K.R., 2003. Influence of food particle size on inter- and intraspecific interactions of Allolobophora chlorotica (Savigny) and Lumbricus ter restris. Pedobiologia 47, 574-577.

MacArthur, R., Levins, R., 1967. The limiting similarity, convergence, and divergence of coexisting species. The American Naturalist 101, 377-385.

Manly, B.J.F., 1995. A note on the analysis of species co- occurrences. Ecology 76, 1109-1115.

Marchinko, K.B., Nishizaki, M.T., Burns, K.C., 2004. Community-wide character displacement in barnacles: a new perspective for past observations. Ecology Letters 7, 114-120.

Margerie, P., Decaëns, T., Bureau, F., Alard, D., 2001. Spatial distribution of earthworm species assemblages in a chalky slope of the Seine Valley (Normandy, France). European Journal of Soil Biology 37, 291-296.

Mouillot, D., Dumay, O., Tomasini, J.A., 2007. Limiting similarity, niche filtering an functional diversity in coastal lagoon fish communities. Estuarine, Coastal and Shelf Science 71, 443.

Nipperess, D.A., Beattie, A.J., 2004. Morphological dispersion of Rhytidoponera assemblages: the importance of spatial scale and null model. Ecology 85 2728-2736.
Nuutinen, V., Pitkänen, J., Kuusela, E., Widbom, T., Lohilahti, H., 1998. Spatial variation of an earthworm community related to soil properties and yield in a grass-clover field. Applied Soil Ecology 8, 85-94.

Oksanen, L., 2001. Logic of experiments in ecology: is pseudoreplication a pseudoissue? Oikos 94, 27-38.

Pižl, V., 1992. Succession of earthworm populations in abandoned fields. Soil Biology and Biochemistry 24, 1623-1628.

R Development Core Team, 2004. R: A Language and Environment for Statistical Computing. R Foundation for Statistical Computing, Vienna, Austria.

Ribera, I., Dolédec, S., Downie, I.S., Foster, G.N., 2001. Effect of land disturbance and stress on species traits of ground beetle assemblages. Ecology 82, 1112-1129.

Ricklefs, R.E., Miles, D.B., 1994. Ecological and evolutionary inferences from morphology: an ecological perspective. In: Wainwright, P.C., Reilly, S.M. (Eds.), Ecological Morphology: Integrative Organismal Biology. University of Chicago Press, Chicago, IL, pp. 13-41.

Ricklefs, R.E., Travis, J., 1980. Morphological approach to the study of avian community. Auk 97, 321-338.

Rossi, J.-P., 2003. Short-range structures in earthworm spatial distribution. Pedobiologia 47.

Rossi, J.P., Lavelle, P., 1998. Earthworm aggregation in the savanna of Lamto (Côte d'Ivoire). Applied Soil Ecology 7, 195-199.

Sanders, N.J., Gotelli, N.J., Heller, N.E., Gordon, D.M., 2003. Community disassembly by an invasive species. Proceedings of the National Academy of Sciences, U. S. A $100,532-535$.

Satoh, A., Ueda, T., Enokido, Y., Hori, M., 2003. Patterns of species assemblages and geographical distributions associated with mandible size differences in coastal tiger beetles in Japan. Population Ecology 45, 67-74.

Scheu, S., 1992. Changes in the lumbricid coenosis during secondary succession from a wheat field to a beechwood on limestone. Soil Biology and Biochemistry 24, 1641-1646.

Schoener, T.W., 1974. Resource partitioning in ecological communities. Science 185 27-39.

Sims, R.W., Gerard, B.M., 1985. Earthworms. Linnean Society of London, London.

Sota, T. Takami, Y., Kubota, K., Ujiie, M., Ishikawa, R., 2000. Interspecific body size differentiation in species assemblages of the carabid subgenus Ohomopterus in Japan. Population Ecology 42, 279-291.

Swenson, T., Weiher, E., 2000. Nellie: Ecological Null Models for the PC. University of Wisconsin, Eau Claire.

Tenenhaus, M., Young, F.W., 1985. An analysis and synthesis of multiple correspondence analysis, optimal scaling, dual scaling, homogeneity analysis and other methods for quantifying categorical multivariate data. Psychometrika 50, 91-119.

Thioulouse, J., Dufour, A.-B., Chessel D., 2004. ade4: analysis of environmental data: exploratory and euclidean methods in environmental sciences.

Topoliantz, S., Ponge, J.-F., Viaux, P., 2000. Earthworm and enchytraeid activity under different arable farming systems, as exemplified by biogenic structures. Plant and Soil 225, 39-51.

Twolan-Strutt, L., Keddy, P., 1996. Above- and below-ground competition intensity in wetland plant communities. Ecology 77, 259-270.

Ulrich, W., Gotelli, N.J., 2007. Null model analysis of species nestedness patterns. Ecology 88, 1824-1831.

Wardle, D.A., 2002. Communities and Ecosystems - Linking the Aboveground and Belowground Components. Princeton University Press.

Weiher, E., Clarke, G.D.P., Keddy, P., 1998. Community assembly rules, morphological dispersion, and the coexistence of plant species. Oikos 81, 309-322.

Weiher, E., Keddy, P.A., 1995. Assembly rules, null models, and trait dispersions: new questions from old patterns. Oikos 74, 159-164.

Wyss, E., Glasstetter, M., 1992. Tillage treatments and earthworm distribution in a Swiss experimental corn field. Soil Biology and Biochemistry 24, 1635-1639. 